\section{Plant parasitic nematodes associated with Indian Pennywort Centella asiatica (L.) Urban in Manipur}

\section{N. Romabati Devi}

Department of Zoology, Modern College, Imphal, Manipur, India Email: ningombamromabati28@gmail.com

The most common nematode species associated with medicinal plants have been recorded from the Silviculture Farm at Kalinga in the district of Phulbani, Orissa (Routaray \& Das 1982), southern Districts (Madurai, Ramanathapuram, Tirunelveli and Kanyakumari) of Tamil Nadu (Samathanam \& Chawla 1982), and Imphal District, Manipur (Romabati et. al. 1992). This study reports plant parasitic nematode species associated with Centella asiatica (L.) Urban in Manipur. Their absolute and relative frequencies and absolute and relative densities are also reported.

Methods: Seventy soil samples including a portion of rootsystem were collected from the rhizosphere of $C$. asiatica from different localities of Manipur. The nematodes were isolated from the soil using Cobb's (1918) sieving and decanting methods and Baermann's funnel technique (Thorne 1961). The nematodes thus, collected were killed and fixed in warm formalin - glacial acetic acid [F: A (4:1)]. The nematodes were identified up to species level and their populations were counted with the help of a Syracuse counting disc. The roots were examined for gall formation by root-knot nematodes. The number of adult root knot nematode females and larvae were counted. Absolute and relative frequencies, and absolute and relative densities of each nematode species was calculated (Norton 1978).

Results: Twenty-one nematode species belonging to 12 genera were identified. Commonly encountered nematode species were Basiria varians, B. graminophila, Tylenchorhynchus mashhoodi, Aphelenchus avenae, T. leviterminalis, Helicotylenchus dihystera, $H$. exallus, $H$. rotundicauda, Cephalenchus lobus and $H$. digonicus. The most prevalent species of plant parasitic

Date of publication (online): 26 December 2009 Date of publication (print): 26 December 2009 ISSN 0974-7907 (online) | 0974-7893 (print)

Editor: Anwar L. Bilgrami

\section{Manuscript details:}

Ms \# 02111

Received 23 December 2008

Final received 28 October 2009

Finally accepted 30 October 2009

Citation: Devi, N.R. (2009). Plant parasitic nematodes associated with Indian Pennywort Centella asiatica (L.) Urban in Manipur. Journal of Threatened Taxa 1(12): 617-618.

Copyright: (C) N. Romabati Devi 2009. Creative Commons Attribution 3.0 Unported License. JoTT allows unrestricted use of this article in any medium for non-profit purposes, reproduction and distribution by providing adequate credit to the authors and the source of publication.

Acknowledgments: The author is grateful to Principal, Modern College, Imphal for providing necessary laboratory facilities.

OPEN ACGESS | FREE DOWNLOAD

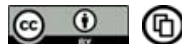

nematodes associated with $C$. asiatica were T. mashhoodi, A. avenae and $H$. dihystera with absolute densities 498, 382,338 per 500g soil respectively. Basiria varians had highest absolute $(100.00 \%)$ and relative frequencies $(7.36 \%)$. However, its density was low as compared to its frequency (Table 1 ).

The absolute and relative frequencies Scutellonema brachyurus, Psilenchus elegans, Pratylenchus thornei and Basiria assarensis were $57.14 \%$ and $4.21 \%$ respectively. The frequency of occurrence of Coslenchus bisuxualis, C. tausifi, Criconemella oblongata, C. ornata, C. serrata and Hirschmanneilla oryzae was less as compared to other nematode species. $M$. incognita was recorded only in 5 samples with very high population.

The relative densities of $T$. mashhoodi, $A$. avenae and $H$. dihystera were $10.82,8.30$ and $7.34 \%$ respectively. The frequencyof B. graminophila Cephalenchus lobus, H. digonicus, Pratylenchus thornei and $B$. assarensis was high but their populations were very low. Other nematode species Coslenchus bisexualis, C. tausifi, Criconemella serrata, C. ornata and Hirschmanneilla oryzae were also recorded at low densities.

Discussion: Samathanam \& Chawla (1982) reported that Helicotylenchus sp. and Meloidogyne sp. were most prevalent nematode genera associated with field crops, medicinal plants and trees in the hilly areas of a southern Districts (Madurai, Ramanathapuram, Tirunelveli and Kanyakumari) of Tamil Nadu. Helicotylenchus abunaamai was most common nematode species associated with a number of medicinal plants grown in a Silviculture Farm at Kalinga in the district of Phulbani, Orissa (Routaray \& Das 1982). The most prevalent and commonly occurring plant parasitic nematodes associated with certain medicinal plants in Imphal were Helicotylenchus sp. and Tylenchorhynchus sp. (Romabati et al. 1992). These results also show species belonging to Helicotylenchus, Meloidogyne and Tylenchorhynchus were prevalent and commonly associated with medicinal plants. Based on the above findings, the most abundantly found nematode species associated with Centella asiatica were Tylenchorhynchus mashhoodi, Aphelenchus avenae, and Helicotylenchus dihystera while Basiria vaians was found to be highest in terms of absolute frequency.

\section{References}

Cobb,N.A. (1918). Estimating the nema population of the soil. $U S$ Department of Agriculture, Bureau. Plant Industry, Agricultural Technology Circular 1: 1-48.

Dhanachand, C. (1998). Nematodes of medicinal plants in Manipur 11: The species of the genus Coslenchus. Uttar Pradesh Journal of Zoology 19(1): 49-52.

Dhanachand, C. (2000). Nematodes of Medicinal plant in Manipur III: On the species of the genus. Sentellonema. Uttar Pradesh Journal of Zoology 20(2): 151-158.

Dhanachand, C. \& N. Romabati (1994). Nematodes of medicinal plants in Manipur. 1. Two new species of Criconematoidea (Nematoda). Proceedings of $2^{\text {nd }}$ Afro-Asian Nematology Symposium, Menoufiya, Cairo, Egypt, 50-53pp.

Norton, D.C. (1978). Ecology of Plant Parasitic Nematodes. John Wiley and Sons, New York, 268pp

Romabati, N., K. Renubala \& C. Dhanachand (1992). Community analysis of nematodes associated with some medicinal plants of Imphal district. Current Nematology 3(2): 167-172.

Routaray, B.N. \& S.N. Das (1982). Association of plant parasitic and free living nematodes with some medicinal plants in Phulbani district (Orissa). Indian Journal of Nematology 12(1): 179-180.

Samathanam, G.J. \& M. L. Chawla (1982). Communtiy analysis of soil 
Table 1. Nematode species identified with their absolute frequency, relative frequency, absolute density and relative density.

\begin{tabular}{|c|c|c|c|c|c|}
\hline & Nematode species & $\begin{array}{l}\text { Absolute } \\
\text { frequency(\%) }\end{array}$ & $\begin{array}{l}\text { Relative } \\
\text { frequency(\%) }\end{array}$ & $\begin{array}{l}\text { Absolute } \\
\text { density(\%) }\end{array}$ & $\begin{array}{l}\text { Relative } \\
\text { density(\%) }\end{array}$ \\
\hline 1 & Basiria varians & 100.00 & 7.36 & 198 & 4.30 \\
\hline 2. & B. graminophila & 92.95 & 6.84 & 158 & 3.43 \\
\hline 3. & Tylenchorhynchus mashhoodi & 91.42 & 6.73 & 498 & 10.82 \\
\hline 4. & Aphelenchus avenae & 91.42 & 6.73 & 382 & 8.30 \\
\hline 5. & T. leviterminalis & 88.57 & 6.52 & 302 & 6.56 \\
\hline 6. & Helicotylenchus dihystera & 87.14 & 6.42 & 338 & 7.34 \\
\hline 7. & H. exallus & 85.71 & 6.31 & 303 & 6.58 \\
\hline 8. & H. rotundicauda & 85.71 & 6.31 & 237 & 5.15 \\
\hline 9. & Cephalenchus lobus & 75.71 & 5.57 & 71 & 1.54 \\
\hline 10. & H. digonicus & 71.42 & 5.26 & 100 & 2.17 \\
\hline 11. & Scutellonma brachyurus & 57.14 & 4.21 & 150 & 3.26 \\
\hline 12. & Psilenchus elegans & 57.14 & 4.21 & 100 & 2.17 \\
\hline 13. & Pratylenchus thornei & 57.14 & 4.21 & 98 & 2.13 \\
\hline 14. & B. assarensis & 57.14 & 4.21 & 68 & 1.47 \\
\hline 15. & Coslenchus bisexualis & 35.71 & 2.63 & 46 & 1.47 \\
\hline 16. & C. tausifi & 32.85 & 2.42 & 28 & 0.60 \\
\hline 17. & Criconemella oblongata & 28.57 & 2.10 & 108 & 2.34 \\
\hline 18. & C. ornata & 28.57 & 2.10 & 68 & 1.47 \\
\hline 19. & C. serrata & 25.71 & 1.89 & 45 & 0.97 \\
\hline 20. & Hirshmanneilla orzyae & 14.28 & 1.05 & 53 & 1.15 \\
\hline 21. & Meloidogyne incognita & 7.14 & 0.52 & 207 & 4.50 \\
\hline
\end{tabular}

and plant parasitic nematodes of hilly areas of southern districts of Tamil Nadu. Indian Journal of Nematology 12: 60-64.

Sinha, S.C. (1996). Medicinal Plants of Manipur. Manipur association for science and society (MASS), Imphal, 238pp.

Thorne, G. (1961). Principles of Nematology. New York, Toranto and London, Mc Graw Hill, 553pp. 